\title{
Impact of Corporate Governance on Internet Financial Reporting in a Growing Economy: The Case Of Nigeria
}

\author{
ASOGWA, Ikenna Elias \\ Department of Accounting, Faculty of Business Management, University of Uyo, Uyo, Akw \\ Ibom State, Nigeria.
}

\begin{abstract}
The study aims at examining the impact of corporate governance on IFR among listed banks in Nigeria. The review of literatures reveal that IFR is one of the most efficient means of communication with investors and the practices of corporate governance by firms also influence their level of disclosures made through the internet. A quantitative research was carried out where the relationship between corporate governance variables and IFR was empirically examined. The corporate governance variables used for analyzing the impact of corporate governance on IFR include shareholders' voting right, percentage of management ownership, percentage of block ownership and percentage of independent directors. The data on the top ten listed banks in Nigeria was collected from secondary sources from year 2010 to 2015. The findings suggest that the measures of corporate governance have significant influence on the level of IFR of banks in Nigeria, it also shows that shareholders' voting right, percentage of independent directors and banks size have significant positive impact on the IFR of banks. The result of the regression analysis show that a negative relationship exists between managerial ownership and block ownership with IFR of Nigerian Banks. It is recommended that listed Nigerian banks should make frequent disclosures of financial information on their websites if they have high shareholder equity as source of fund in capital structure and also to attract investors and show transparency.
\end{abstract}

KeyWords: Corporate Governance, Internet financial reporting, Banks, Nigeria.

\section{Background of the Study}

\section{INTRODUCTION}

Corporate failures in Nigerian banks had resulted due to poor corporate governance mechanisms and bad financial reporting system (Asogwa, 2016). A sound and efficient financial reporting system through the internet will enhance the performance of Nigeria banking sector, increase its access to a global audience and attract more investors through effective disclosure (Abdelsalam et al; 2007). A robust disclosure regime brings transparency and serves as a strong tool for enhancing stakeholder management. According to Asogwa (2016), effective and efficient internet disclosure coupled with a good corporate governance structure will attract more capital, reduce fraud and sustain the confidence of investors in the capital market. Nigeria is a middle income, emerging market and mixed economy and currently growing her entertainment, manufacturing, technological, financial service industry and so on.

Besides currently ridden with the scourge of recession, Nigeria was ranked the $3^{\text {rd }}$ fastest growing economy in the world early 2015 by CNN Money with an estimated Gross Domestic Product (GDP) of about $\$ 510$ billion (Asogwa, 2016) but has significantly dropped to $22^{\text {nd }}$ largest economies in the world according to International Monetary Fund (IMF) ranking in the 
late 2016 release. With about $\$ 492.9$ billion nominal GDP and $\$ 1105.3$ billion Purchasing Power Parity (PPP), Nigeria is not among the top 15 fastest growing economy in Africa in 2016 (Vanguard news). All these back and forth growth, makes Nigeria a country of interest for a study of this kind in order to reflate the economy through efficient banking.

The internet is a disclosure tool which is unique and encourages different types of presentation and allows inexpensive, broad and immediate communications to investors. Most of the practices of Internet Financial Reporting (IFR) in Nigeria are voluntary and unregulated. The majority of the corporations select to disseminate information on their firm's websites voluntarily but the IFR significance varies according to corporations (Ashbaugh et al., 1999; Umoren and Asogwa, 2013) Previous studies have indicated that the transparency variation of the financial disclosures online influences the decision process of the investors (Hodge et al., 2004). Investors use the internet to get financial information relating to the current and potential opportunities of investment. IFR is the tool which can lead to an enhanced information transparency disclosure since "the ways Banks report has been drastically changed due to the internet" (Kelton and Yang, 2008). In comparison with paper-based and traditional disclosures, IFR helps corporations to disseminate the information to a much bigger and broader audience. It also allows distribution of alternative kinds of disclosures on a timely basis. Moreover, the technologies based on internet allow firms to use alternative presentation formats of information (e.g. PDF, Word, Hypertext and Multimedia) which enhances the way investors understand and access information. Hodge et al., (2004) opined that, "technologies which allow the formats alternatives for the dissemination of financial information may support gathering of information from investors, influence decision making process and enhance the transparency disclosures". Therefore, the corporation can enhance the transparency disclosures with both the presentation and the content format for disclosures on internet.

The mechanisms of corporate governance also influence the disclosure policy of firms (Ho and Wong, 2001). The adoption of corporate governance practices can lead a firm towards making disclosures on internet as it will lead to reduction of agency costs and help in attracting investors by reducing information asymmetry that exists between managers and investors in the market (Asogwa, 2016). The research explores the corporate governance impact on IFR in Nigeria

\section{HYPOTHESES}

Agency theory provides a framework that links managerial behaviours to corporate governance. The theory explains that the cost of agency arises due to the interest conflict between the managers and the shareholders. Agency problem occurs when the interest of the principal (shareholders) and the manager (the agent) are in conflict and when the attitude to risk varies. Disclosure is viewed as an agency cost, necessary for the monitoring of management to ensure goal congruence with shareholders. The economic advantages of the costs of agency reduction will be shared by the managers and the shareholders in most of the situations of the market. Due to this, the managers mostly undertake voluntary actions comprising of submissions and disclosures to monitoring.

The mechanisms of governance role in identifying the policy of disclosure may either be substitutive or complementary. The policy disclosure is complementary when the mechanisms of corporate governance strengthen the controls internally for the corporation. This also makes it less likely to withhold information for the managers for their own advantages. This paves the way towards enhancement of comprehensive disclosures and in improving financial statement quality. On the other side, the substitutive mechanism of corporate governance 
limits information asymmetry and the behaviours of opportunistic in the corporation leading to decrease in the need for more disclosure and monitoring.

The corporation's disclosure transparency of financial information is linked with the information dissemination methods (Kelton and Yang, 2008). Information technology innovations have allowed Banks to enhance their transparency disclosure with alternative processes like IFR. According to Roger, Glen and Asheq (2002), "The management provided the internet the opportunity to provide and access all investors the essential updates of information." Thus, with the help of IFR, transparency disclosure of the firm can be enhanced. So, the hypothesis is stated in the alternate form.

\section{H1: Internet based disclosure of listed Nigerian Bank's is linked negatively with the shareholder rights}

In this research, corporate governance is measured by ownership structure, shareholder rights, audit committee characteristics and board composition. The rights of the shareholders vary according to corporations. Some firms (the minority) have less power reserved for management and they quickly and easily allow shareholders to replace their directors. This can be done either through AGM voting or internal or external takeover. On the other hand, other firms have more power reserved for their management and they impose robust restrictions on the replacement of directors by shareholders. When the rights of shareholders decrease, the replacing management costs also increases for shareholders. Because of this, the cost of agency increases. Corporations are expected to respond to the increase in agency costs with the transparency disclosure increase. In consequence to that, the firms which have weak rights of shareholders have more chances to engage in IFR as compared to the firms with robust right of shareholders.

\section{H2: Internet based disclosure of listed Nigerian Bank's is linked negatively with managerial ownership}

This study examines the effect of corporate structure of ownership on IFR using block ownership and managerial ownership measures. In situations where management has significant ownership rights, the conflicts of agency are reconciled between shareholders and managers and thus agency costs are reduced. Empirical research has shown that managerial ownership is linked with an increase in productivity and innovation of the corporations in the long term value of firms. As managerial ownership aligns the managers and shareholders' interests, it limits the demands of monitoring for shareholders. Thus, the impact of ownership on IFR is deemed to be substitutive such that the need for more transparent disclosure and more monitoring is reduced by an increased percentage of managerial ownership. This sort of ownership is associated negatively with the disclosure which is voluntary in Nigerian Banks (Conway, 2012). So, according to that, the hypothesis is tested in the form of alternative.

\section{H3: Internet based disclosure of listed Nigerian Bank's is linked negatively with block ownership}

Block ownership refers to the outside interests holding more than $5 \%$ of shares outstanding. When the ownership of shares is less diffused, there is limited monitoring required. Previous research has indicated a negative relationship between disclosure and block ownership (Sayogo, 2006). So, the impact on IFR of the block holder ownership is substitutive. According to that, the hypothesis is tested in the form of alternative. 


\section{H4: There is no link between internet based disclosure of listed Nigerian Bank and its independent director's proportion on the board.}

A significant proportion of independent directors on the Board of Directors reduces the opportunism of managerial monitoring and reduces the chance of withholding information for management. Empirical research has suggested that a strong link exists between the independence of board and disclosure of corporation (Xiao and Jones, 2005).

Jiang and Raghupati (2010) showed that the independent board of directors are linked positively to the disclosure decisions of the board. A positive relation exists between the proportion of independent director and the comprehensive disclosure of corporate governance data in context of Nigerian Banks (Ajinkya et al. (2005). They showed that the corporations that have a high percentage of external directors are more likely to issue earnings forecasts. In contrast to these findings, Gandia (2005) revealed that, for Nigerian firms, external directors increased presence is linked with the reduction in disclosure. The findings by Gandia (2005) show that the directors which are independent play a role of substitute monitoring which leads to a decline in the additional disclosure demands. So, according to that, the hypothesis is tested in the form of alternative.

\section{RESEARCH QUESTIONS}

The relationship between corporate governance practices and the disclosure of the banks for transparency will be examined for the past 6 year's period that is 2010 to 2015. This is used to determine the quality and evaluate the IFR extent of disclosure and the impact of this investigation on economic growth in Nigeria. The research questions are as follows;

- To evaluate corporate governance information disclosure on the website of Nigeria's listed banks.

- To investigate the relationship that exists between corporate disclosure and web-based disclosure.

- To analyse the viability and the ability of Nigeria's listed banks to communicate financial information that is useful for both the analysts and the investors with the help of internet.

\section{Corporate Governance of banks in Nigeria}

Corporate governance issues in Nigeria has gained the attention of researchers due to increases in privatization of corporate entities and development of corporate sectors (Ranti, 2011). Banks corporate governance involves methods used by bank shareholders to induce managers for wealth maximization (Asogwa, 2016). Just as the case in many developing economies, the Nigerian banking sectors has recorded a number of cases of fraud, misappropriation and other financial irregularities and ultimately bank failures that adherence to good corporate governance practices could curb. Academic scholars in Nigeria understand the urgent need to develop a sound corporate governance in business following the increases in corporate scandals in the US coupled with the recent bank scandal in Nigeria that led to the recapitalization of Nigerian banks by the Central Bank of Nigeria (CBN) in 2010. In line with Ranti (2011), an efficient and robust corporate governance structure is crucial in Nigeria for proper working of the corporate sectors (Bhasin, 2012). Ogbechie (2006) noted that the Bankers Committee of Nigeria set up a sub-committee for the implementation of the corporate governance mechanism in Nigeria having realized the importance of corporate governance to the success of any business entity. "The pursuance of corporate governance mechanisms ensure the financial viability of corporate businesses as through it all the affairs of the firm are managed effectively and directed towards the creation of value for the shareholders" (Asogwa, 
2016). According to Pereiro (2002) and Damodaran (2006), disclosure of corporate financial information on timely basis creates value for the firm and shareholders as the information is spread.

However, Companies and Allied Matters Act (CAMA) 1990, the Investment and Securities Act (ISA) 1999 and the Bank and other Financial Institution Act (BOFI) were the three main bodies that oversees the operations of the corporate sector before the setting of the corporate governance code in 2002. As a result of the challenges the body faced with the provisions, another committee was established in association with the Securities and Exchange Commission (SEC) and Corporate Affairs Commission (CAC) for the development of corporate governance code to be used by corporate entities which by extension guided the operations of the banks in Nigeria.

\section{Internet Financial Reporting}

According to Bushman et al., (2004), firms in today's world enhance their disclosure transparency through various means. Among the various means of information dissemination, the internet is one of the most valuable tool which provides the firm management an opportunity to daily update their stakeholders about the important corporate information and an ability to access the potential investors as well (Healy and Palepu, 2001). According to Robinson and Munter (2004), the reporting of high quality corporate financials is essential for presenting the fair financial position and operations of corporations. According to them, there are four reasons behind low quality reporting. These include application of standards by selecting those alternatives which lead towards the reporting of results in bias or distorted manner. The accounting principles applied by the firms may have loopholes and the practices of assumptions or estimation done by using inappropriate or unrealistic measures. The firms are said to have low quality financial reporting when the accounting principles are stretched in a firm or the managers are engaged in reporting of financials in a fraudulent way. Outa (2014) emphasized that for enhancing the transparency in financial reporting, firms are required to show compliance with the high quality standards of accounting. These standards are required to be enforced on priority basis for enhancing the relevance, comparability, understandability and reliability of investors on corporate financial information. In order to overcome the problems of accounting frauds in businesses, the regulatory bodies such as SEC has also encouraged corporations to disclose their information on their corporate websites in response to realization of benefits of internet in dissemination of information.

According to Ajinkya et al., (2005), the adoptions of various means in dissemination of information by corporation for enhancing the level of transparency proves that strong measures of corporate governance are promoted within the corporations. The firm disclosure of financial information through internet was initially a voluntarily practice and most of the firms disclose their information on official websites voluntarily. Ajinkya et al., (2005) observed that disclosures made on the corporate websites are unregulated and varies from firm to firm. However, the use of internet proves as a valuable tool for firm information disclosure (Ettredge et al., 2002). The literature on internet financial reporting reveals new insights on the reason why companies are choosing internet as a tool for the information disclosure (Ashbaugh et al., 1999; Ettredge et al., 2002 and Debreceny et al., 2002).

Ashbaugh et al., (1999) explored the difference between corporations that use their official websites for dissemination of information to the investors and corporations that do not use it. The findings revealed that the firms which choose corporate websites for dissemination of information are more profitable as compared to others. The authors reported that the main 
reason behind using internet as a tool for information disclosure is to inform shareholders about the firm performance on time.

Ettredge et al., (2002) classified IFR disclosure into two categories. One category include the voluntary disclosure made by the corporations while the second category considers the required filings which include the disclosures in the form of Forms $10 \mathrm{Q}$ and 10-k made mandatory for firms by SEC. Ettredge et al., (2002) investigated that dissemination of information through internet by corporations as a voluntary disclosure and required filing is in accordance with the traditional approach followed for voluntary disclosures in incentive theories or not. The findings of the study reveal that required filings are presented on corporate websites as they are found to have an association with information asymmetry and size of corporations. The voluntary disclosures on the corporate websites are made by the corporate managers not due to having association with information asymmetry and size but also due to having a link with earning goodwill and to attract investors for raising external capital. This thought follows the view of Damodaran (2006) and in aligns with the author's view.

\section{Internet Financial Reporting and Corporate Governance}

The main area of focus in the earlier literature on IFR was the estimation of the determinants of IFR. Ashbaugh et al., (1999); Ettredge et al., (2002); Debreceny et al., (2002), and Oyelere et al., (2003) suggested a number of different firm specific factors, for example financial leverage, firm profitability and size of firm. The recent studies now focus on association between IFR and measures of corporate governance such as board size, type of ownership and other measures of corporate governance with the policy of disclosure for example timing, quality, mandatory disclosure or voluntary disclosure etc (Beasley, 1996; Klein, 2002; Xiao et al., 2004; Sengupta 2004; Gul and Leung, 2004; Ajinkya et al., 2005).

According to Jensen and Meckling (1976), the link between the corporate governance and disclosure behaviour of firms can be explained by the agency theory perspective. With the viewpoint of agency theory, the agency cost exists between the managers and shareholders due to divergence of interest of both the parties. Pratt and Zeckhauser (1985) stated that the benefits that are achieved through the minimization of this agency cost are shared by both the parties that are agent (managers) and principal (shareholders). Considering the sharing of economic benefits, the managers in a firm take a number of voluntary actions for minimization of agency cost such as disclosure of information and accept the monitoring of their performance (Xiao et al., 2004). Ho and Wong (2001) stated that the mechanism of corporate governance determines the disclosure policy of management as the mechanism of governance required by the firm can be complementary or substitutive. The adoption of corporate governance practices in organization will play a complementary role when these practices are found to be the strength for the measures of internal control. In such a situation, it is assumed that the managers in the organization will reserve corporate information not for their private benefits but for benefitting the shareholders. The information disclosed by them in corporate disclosures aims at bringing an improvement in the quality of financial information and to increase its level of comprehensiveness. In contrast to this, the practices of corporate governance will serve a substitutive role in situations where a firm reduce their opportunistic behaviors and tries to lower the level of information asymmetry that exists between managers and shareholders. In the substitutive role of corporate governance, the firms feel less need for making corporate disclosures voluntarily and principles are required to put less effort for monitoring of firm performance. 
The study conducted on Chinese firms by Xiao et al., (2004) investigated the relationship between IFR and corporate governance as determinants of IFR. The analysis of IFR was made in various dimensions: content displayed on corporate websites, voluntary disclosures and required filings by SEC. The findings show that the internet financial reporting has a significant positive association with institutional ownership in Chinese firms. The results disclosed that there is no significant link between IFR and ownership in the firms of foreign, domestic or private investors.

Kelton and Yang (2008) examined the link between measures of corporate governance and firm disclosure policy by examining the official websites of 248 companies that trade on NASDAQ. The study has used shareholders rights, type of ownership structure, and composition of board and characteristics of corporate audit committees as measures for the corporate governance in these firms. The firm level of internet financial reporting is used as a proxy for measuring the disclosure transparency of selected firms. For that purpose, a disclosure index was constructed in the study. The internet financial reporting index is made up of format of financial presentation, disclosure of corporate governance information and content of information displayed on corporate websites. The findings reveal few characteristics of firms which disclose their information on internet. The characteristics of firm which make IFR disclosures identified by them are weak rights of shareholders, block holders in the firm are in lower percentage, audit committees in a firm are made up of financial experts and a hardworking and committed audit committee, corporate boards are made up of independent directors etc. The authors were of the view that incorporation of corporate governance practices will have a significant influence on disclosure behaviour of firms on internet as it is expected that the incorporation of these practices will lead to reduction of agency costs and help in attracting investors by reducing information asymmetry that exists between managers and investors in the market. It was also noted that the association between corporate governance and IFR also varies with respect to the size of organizations. The study recommends the organizations to work on development of new regulations for corporate governance for enhancing the transparency of corporate financial disclosures made using internet as a tool for information dissemination.

\section{Internet Financial Reporting and Corporate Governance in Nigeria}

The literature on the issue of corporate governance and IFR and their influence on each other in Nigeria is limited. The literature provides conflicting results on the measures of corporate governance (for example insider ownership, ownership concentration) and firm performance and influence of corporate governance measures on corporate disclosure practices in Nigeria (Umoren and Asogwa, 2011; Ezi-Herbert and Tesgba, 2010). However, the review of recent literature on IFR and corporate governance is discussed below.

Emmanuel, Oki and Maimako (2015) analyzed the published annual reports of ten Nigerian listed banks. The years selected for the analysis included 2000 to 2009. By applying regression analysis, the authors proved that the disclosure of corporate governance practices in banks annual reports has a positive impact on the performance of banks. The authors said that an increase in level of disclosures by the banks led them to the delivery of better performance.

Kurawa and Kabara (2014) examined the impact of corporate governance measures on the voluntary disclosures of firms belonging to the Nigerian petroleum sector. The period selected for examination of impact was 2001 to 2010. The sample selected for the analysis includes seven firms on which data was collected through secondary sources. The data collected in the study was analyzed by using descriptive statistics and regression analysis. The results obtained 
from estimations revealed that ownership concentrations hold a significant positive association with the voluntary disclosures by firms in Nigeria. However, the findings revealed an insignificant link with the composition of board. In addition to this, the findings have also showed a negative association of managerial ownership and existence of duality in the firm on the level of disclosures made by firms.

Ejuvbekpokpo and Esuike (2013) in their study on issues and problems arising from corporate governance in Nigeria stated that it is necessary for corporations to bring quality in their disclosures through different means. It is essential for assuring the investors that the information presented to them is transparent and their interest is secured. Ranti (2011) found that the governance mechanism of Nigerian banking sector is weak, despite the policy to consolidate the banks launched in 2004 by the central bank of Nigeria. Sanusi (2010) reported that the banks in Nigeria are involved in doing business through unethical and fraudulent practices. The incidences of malpractices in the banks are reported due to negligence of board as boards are not performing their fiduciary duties in an effective way to boost economic development of Nigeria. In addition to the reason behind the weak governance is that the audit processes in the banks are not effectively carried out as banks that were said to be financially stable after their audit were proven to be in dire financial problems that led to their failures.

The above review of the limited literature available shows that there is a need to conduct a new study for having conclusive findings on the issue of corporate disclosure and its association with measures of corporate governance in Nigeria. This study is based on the examination of association between measures of corporate governance and disclosure transparency using IFR as its measure in the growing economy of Nigeria.

\section{Sample and Data collection}

The sample selected for the study will include 10 largest banks listed on Nigerian Stock exchange in Nigeria. The data for the selected variables of the study will be collected from annual reports of the selected banks and from the official websites of the banks. The data on the selected variables will be collected for year 2010 to 2015 and analyzed by running the data in SPSS (Statistical package for social sciences). Table 3.2 presents the list of banks selected for the study

Table 3.2: List of Banks

\begin{tabular}{|l|l|}
\hline S/No & List of Banks selected \\
\hline 1 & Zenith Bank \\
\hline 2 & Access Bank Plc \\
\hline 3 & United Bank for Africa \\
\hline 4 & Union Bank \\
\hline 5 & First Bank \\
\hline 6 & GT Bank \\
\hline 7 & Fidelity Bank \\
\hline 8 & Diamond Bank \\
\hline 9 & FCMB \\
\hline 10 & Wema Bank \\
\hline
\end{tabular}

\section{DATA ANALYSIS}

The data collected through the secondary sources will be analyzed by running the data in SPSS. The statistical tools used for analyzing the data will include descriptive statistics, correlation analysis and regression analysis. In descriptive, the mean, maximum, minimum and standard 
deviations for the variables selected in the study will be calculated. Pearson's Correlation analysis will be used for examining the linear relationship that exists between the variables. The regression analysis will be employed in the research for determining the impact of corporate governance on IFR of listed banks in Nigeria. The application of regression analysis helps in testing the hypothesis proposed for the study and for disclosing the relationship between measures of corporate governance and IFR.

\section{RESEARCH MODEL}

For determining the impact of corporate governance on IFR of Nigerian banks, the following regression model will be examined by running the data in SPSS.

\section{IFR $=\mathrm{C}+\boldsymbol{\beta}_{1} \mathrm{Gov}+\boldsymbol{\beta}_{2} \mathrm{MO}+\boldsymbol{\beta}_{3} \mathrm{BO}+\boldsymbol{\beta}_{4} \mathrm{ID}+\boldsymbol{\beta}_{5} \operatorname{logsizeP}+\boldsymbol{\beta}_{6} \mathrm{Loss}+\boldsymbol{\beta}_{7} \mathrm{BIG} 4+\varepsilon$}

Where Gov = Governance, $\mathrm{MO}=$ percentage of managerial ownership, $\mathrm{BO}=$ percentage of block ownership, ID $=$ Percentage of independent directors on board, size $=$ Size of firm, loss= loss made by a firm in operating year, BIG4 $=$ Auditor of firm, $\mathbf{C}=$ constant, $\boldsymbol{\beta 1}=$ coefficient of Governance, $\boldsymbol{\beta}_{2}=$ coefficient of percentage of managerial ownership, $\boldsymbol{\beta}_{3}=$ coefficient of percentage of block ownership, $\boldsymbol{\beta}_{4}=$ coefficient of Percentage of independent directors on board, $\boldsymbol{\beta}_{5}=$ coefficient of Size of firm, $\boldsymbol{\beta}_{6}=$ coefficient of loss made by a firm in operating year, $\boldsymbol{\beta}_{5}=$ coefficient of Big 4 and $\boldsymbol{\varepsilon}=$ Error term of model.

In the model, IFR will be the dependent variable of the study, the set of independent variables in the study includes Governance, managerial ownership, block ownership, independent directors from year 2010 to 2015. The set of control variables in the model include three variables. These are size, loss and Big 4 . The selection of variables for the study is made in accordance with Kelton and Yang (2008).

\section{Dependent variables}

\section{RESEARCH VARIABLES}

The dependent variable of the study is IFR which was measured by an index made up of content and presentation. The index was constructed by making a list of 10 Items to whom each item was given value 1 on presence and 0 in the case of absence. The data on the IFR will be collected from the official websites of banks selected in the study. The index used for measurement of IFR is presented below in the following table

Table 3.3.1 Dependent variable (IFR)

\begin{tabular}{|l|l|}
\hline Format Items & \\
\hline 1 & Annual report in multiple file forms \\
\hline 2 & Financial data in processible form \\
\hline 3 & Hyperlinks established \\
\hline 4 & Drop down navigational menu \\
\hline 5 & Facility of direct email for investors \\
\hline Content Items & \\
\hline 6 & Annual report for recent year \\
\hline 7 & Annual report for last year \\
\hline 8 & Quarterly reports for recent year \\
\hline 9 & Financial news for the recent period \\
\hline 10 & Record of stock prices \\
\hline
\end{tabular}




\section{Independent variables}

The sets of independent variables of the study include governance, managerial ownership, block ownership and independent directors in the board. The governance variable was used in the study as a proxy for shareholder rights in banks. It was given value 1 when shareholders have voting rights and 0 in the absence of voting rights. The variable managerial ownership represents the ownership of management in company shares and is expressed in the form of percentages. The variable block ownership expressed in percentages represents the percentage of shareholders who have equity of more than $5 \%$ in the banks. The variable independent directors in the study were measured by percentages and show the percentage of independent directors present in the bank's board. The data on these variables are collected through the annual reports and official websites of the banks.

\section{Research Limitations}

The study posed certain limitations like;

- The population representative may not be true to the sample

- The results achieved cannot be applicable globally in its entirety

- The sample size of the population may be biased

- The professionals of business were reluctant to give proper information

\section{Results}

\section{RESULTS AND ANALYSIS}

The data for examining the impact of corporate governance on internet financial reporting of top 10 banks in Nigeria was analysed using descriptive analysis, correlation analysis and regression analysis. The findings of each analysis performed are discussed in detail as below;

\section{Descriptive Analysis}

The basic features of data collected for top ten listed bank in Nigeria for the six years perod were analyzed by performing descriptive analysis. An attempt was made to find the minimum values, maximum values, mean and standard deviation values for IFR, governance, percentage of managerial ownership, percentage of block holders, independent directors, size of firm, loss and big4. The results are presented in Table 4.1. In the table, the IFR value shows the ranking of Nigerian banks on IFR index in six years. The Gov, loss and Big 4 are binary variables, where 0 refers to absence of variable in the selected years and 1 shows the variable presence. The variables MO, BO and ID are measures in percentages while the size is measured in terms of total equity of firm whose unit of measurement is Nigerian naira (000).

Table 4.1:Descriptive Statistics

\begin{tabular}{|l|l|l|l|l|l|}
\hline & N & Minimum & Maximum & Mean & Std. Deviation \\
\hline IFR & 50 & 3 & 10 & 6.89 & 2.543 \\
GOV & 50 & 0 & 1 & .80 & .404 \\
MO (\%) & 50 & .0160 & 1.9000 & .853040 & .6220372 \\
BO(\%) & 50 & .0000 & 85.0000 & 29.107800 & 25.0553974 \\
ID(\%) & 50 & .0000 & 33.3333 & 15.730660 & 10.1581153 \\
SIZE(NGN, 000) & 50 & 13589 & 277410727 & 61643195.10 & 83349048.722 \\
LOSS & 50 & 0 & 1 & .10 & .303 \\
BIG4 & 50 & 1 & 1 & 1.00 & .000 \\
Valid N (listwise) & 50 & & & & \\
\hline
\end{tabular}


The descriptive statistics presented in Table 4.1 show that the mean value of financial disclosures made by Nigerian Bank on internet is 6.89 on 10 point index. This shows that banks in Nigeria are putting efforts for enhancing their transparency and disclosure of financial information on their website. The maximum value of IFR is 10 for those banks who have all items of content and format selected in the index. The maximum score of 10 is achieved when banks have multiple formats of annual reports, financial data in processed form, hyperlinks established, drop down navigational menu, and have facility of direct email on website. Further, they have annual reports of recent year and previous year, quarterly financial data, recent financial press releases and record of stock prices on their official websites. The minimum value of IFR in the data is 3 . The descriptive analysis for IFR shows that banks in Nigeria have more emphasis on disclosing items of content than having focus on format of presentation.

The mean value of governance used as a proxy for shareholders voting rights has a mean value of 0.80 . As shown in the model 0 shows absence of shareholders voting rights and 1 represents presence of shareholders voting right, the mean value 0.80 being closer to 1 means that the majority of banks in Nigeria have given voting rights to shareholders. This means that shareholders of Nigerian banks are delegated with a power to vote and are allowed to participate in making financial decisions and decisions related to board of director's appointment or removal (Dallas, 2004). The mean value for percentage of managerial ownership in Nigerian banks is $0.8530 \%$ with standard deviation of $0.6220 \%$. The minimum value of percentage of managerial ownership in Nigerian banks is $0.0160 \%$ and the maximum value for it in data is $1.9 \%$. The descriptive analysis for managerial ownership shows that managers have low level of ownership in Nigerian Banks which shows that the interest of managers are not streamlined with the interest of shareholders. The percentage of shares held by block holders in the Nigerian banks has mean value of $29.10 \%$ with the standard deviation of $25.10 \%$ from the mean. The descriptive statistics for block holders' ownership show that maximum value for block holder's ownership in Nigerian banks is $85 \%$ whereas as the minimum value for data is 0 as there are few banks in data which have no shareholders with equity more than 5\%. The presence of high level of block ownership in Nigerian banks influences the participation of minority shareholders in corporate affairs hence shows that minority shareholding is not advantageous in Nigerian banks.

The minimum percentage of independent directors in Nigerian banks is 0 and maximum percentage for independent directors is $33.33 \%$ in their board. The results of descriptive analysis show that banks in Nigeria usually have an average of $15 \%$ of independent directors in their boards. However, this value can deviate from the mean with the standard deviation of $10.15 \%$. The low percentage of independent directors in the boards of Nigerian banks show that independent director's presence in the board is not preferred due to weak corporate governance practices in Nigeria. The independent directors act as referee in the board and protect the shareholders rights by forcing managers not to make unbiased decisions (Tomasic and Bottomley, 1993).

The size of Nigerian banks measured in terms of equity has mean value of 61643195.10 NGN. The minimum values of banks size in the data is 13589 NGN and have maximum value of 277410727 NGN. The data for Big4 show that all the selected banks in the analysis have employed Big4 auditors for giving an opinion on the financial disclosures made. Further, the dummy variable for loss show that majority of banks remained profitable in years under analysis. 


\section{Correlation Analysis}

The correlation analysis was performed for analyzing the existence of linear relationships that exists between the set of independent and control variables with IFR of Nigerian banks. Table 4.2 explains the results of pairwise correlation that IFR holds with the measures of corporate governance which include governance, managerial ownership, block holders ownership and percentage of independent directors in Nigerian bank boards. The results of correlation analysis are presented in the form of symmetrical matrix where diagonal cells have value 1 showing the correlation of variables with themselves.

Table 4.2: Correlation Analysis

\begin{tabular}{|c|c|c|c|c|c|c|c|c|c|}
\hline & & IFR & GOV & MO & BO & ID & LOG(SIZE) & LOSS & BIG4 \\
\hline \multirow{3}{*}{ IFR } & Pearson Correlation & 1 & .125 & $-.565^{* *}$ & .282 & .288 & .194 & -.048 & \\
\hline & Sig. (2-tailed) & & .413 & .000 & .061 & .055 & .202 & .753 & \\
\hline & $\mathrm{N}$ & 45 & 45 & 45 & 45 & 45 & 45 & 45 & 45 \\
\hline \multirow{3}{*}{ GOV } & Pearson Correlation & .125 & 1 & .254 & -.275 & .069 & $-.458^{* *}$ & -.167 & $\mathrm{~b}$ \\
\hline & Sig. (2-tailed) & .413 & & .075 & .053 & .632 & .002 & .247 & . \\
\hline & $\mathrm{N}$ & 45 & 50 & 50 & 50 & 50 & 45 & 50 & 50 \\
\hline \multirow{3}{*}{ MO } & Pearson Correlation & $-565^{* *}$ & .254 & 1 & $.573^{* *}$ & .185 & .237 & -.229 &. \\
\hline & Sig. (2-tailed) & .000 & .075 & & .000 & .197 & .117 & .109 & \\
\hline & $\mathrm{N}$ & 45 & 50 & 50 & 50 & 50 & 45 & 50 & 50 \\
\hline \multirow{3}{*}{ BO } & Pearson Correlation & .282 & -.275 & $-.573^{* *}$ & 1 & $.303^{*}$ & .231 & .052 & b \\
\hline & Sig. (2-tailed) & .061 & .053 & .000 & & .032 & .126 & .718 & . \\
\hline & $\mathrm{N}$ & 45 & 50 & 50 & 50 & 50 & 45 & 50 & 50 \\
\hline \multirow{3}{*}{ ID } & Pearson Correlation & .288 & .069 & .185 & $-.303^{*}$ & 1 & .001 & $-.329^{*}$ & $\mathrm{~b}$ \\
\hline & Sig. (2-tailed) & .055 & .632 & .197 & .032 & & .996 & .020 & 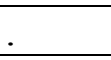 \\
\hline & $\mathrm{N}$ & 45 & 50 & 50 & 50 & 50 & 45 & 50 & 50 \\
\hline \multirow{3}{*}{ LOG(SIZE) } & Pearson Correlation & .194 & $.458^{* *}$ & .237 & .231 & .001 & 1 & -.116 & $\mathrm{~b}$ \\
\hline & Sig. (2-tailed) & .202 & .002 & .117 & .126 & .996 & & .448 & . \\
\hline & $\mathrm{N}$ & 45 & 45 & 45 & 45 & 45 & 45 & 45 & 45 \\
\hline \multirow{3}{*}{ LOSS } & Pearson Correlation & -.048 & -.167 & -.229 & .052 & $.329^{*}$ & -.116 & 1 & $\mathrm{~b}$ \\
\hline & Sig. (2-tailed) & .753 & .247 & .109 & .718 & .020 & .448 & & . \\
\hline & $\mathrm{N}$ & 45 & 50 & 50 & 50 & 50 & 45 & 50 & 50 \\
\hline \multirow{3}{*}{ BIG4 } & Pearson Correlation & b &.$^{b}$ &.$^{b}$ &.$^{b}$ &.$^{b}$ & b &.$^{b}$ &.$^{b}$ \\
\hline & Sig. (2-tailed) & . & & & & & & & \\
\hline & $\mathrm{N}$ & 45 & 50 & 50 & 50 & 50 & 45 & 50 & 50 \\
\hline
\end{tabular}

The results of correlation analysis presented in Table 4.2 show that the dependent variable IFR holds positive, but weak, correlation with the governance variable that was used as proxy for shareholders rights in Nigerian banks. The results show that the value of correlation coefficient between IFR and governance in Nigerian banks is 0.125 . This relationship is however not significant at any level of significance. The presence of insignificant correlation between IFR and percentage of managerial ownership contradicts the findings of Kelton and Yang (2008) who found a positive but significant relationship between the two in their study on impact of 
corporate governance on IFR. The value of correlation coefficient between IFR and percentage of managerial ownership in banks is -0.565 . The correlation coefficient reveals that there exist a negative relationship between IFR and managerial ownership. This relationship is found to be significant at $1 \%$ level of significance. The findings show that an increase in transparency of banks by making financial disclosures on website will decrease the level of managerial ownership in the banks. The findings of correlation analysis for Nigerian banks here are in accordance with the Eng and Mak (2003) who also found a negative relationship of managerial ownership with IFR of firms operating in Singapore. The findings of pairwise correlation for IFR and percentage of block holder ownership in Nigerian banks show the existence of positive, but weak, correlation between the two as the value of coefficient is 0.282 . This relationship is observed not to be significant at any level of significance. The presence of weak and positive relationship contradicts the findings of Mitchell et al., (1995) and Schadewitzand Blevins (1998) who had also observed a negative association of block holder's ownership with the level of IFR.

A positive, but weak and insignificant, correlation was found between IFR and percentage of independent directors as the value of correlation coefficient was 0.288 with no significance at any $1 \%$ or $5 \%$ level of significance. The findings are against the findings of Beasley (1996), Chen and Jaggi (2000) and Xiao et al., (2004) who believe that an increase in level of independent directors in the board will significantly enhance the transparency of banks and lead to an increase in financial disclosures on official websites.

The values of correlation analysis also reveal an insignificant, weak and positive correlation between log of size and dependent variable IFR. The correlation coefficient for these two is 0.194. The results for loss made by the banks in the operating years and IFR show that negative correlation exist between IFR and loss of banks. The value of correlation coefficient for IFR and loss is -0.048 .

Among the correlations between the other variables, the correlation analysis shows that a negative but significant relationship exists between the loss made by banks and their governance. The value of correlation coefficient for these two is -0.458 and is significant at $1 \%$ level of significance. The results show that the increase in the losses of banks in operating years will lead to decrease in their level of governance. The correlation coefficient in correlation matrix for percentage of managerial ownership and percentage of block holders is 0.573. The value indicates the presence of negative correlation between the two which is significant at $1 \%$ level of significance. This negative relationship indicates that the level of managerial ownership in bank decrease with an increase in level of block holders in Nigeria banks. Similar to relationship between percentages of managerial ownership, the percentage of block holders ownership holds a significant and negative correlation with the percentage of independent directors in case of Nigerian banks. The value of correlation coefficient in this case is -0.303 which is significant at $5 \%$ level of significance. The findings of correlation analysis also show that percentage of independent directors holds negative but significant with the loss made by the banks in operating year. Here, the value of coefficient is -.329 which is significant at $5 \%$ level of significance.

\section{Regression analysis}

The regression analysis was performed on the model constructed for the study with IFR as dependent variable in the model. The regression model proposed for the study is based on four independent variables that are used as a measure of corporate governance. The set of independent variables include governance, percentage of managerial ownership, percentage of 
block holder's ownership and percentage of independent directors in the board. The control variables of the study were loss, big4 and size of banks. Multiple regression analysis was performed for examining the impact of corporate governance on IFR of banks in Nigeria. The findings of model best fit for study are presented below in the followings tables (Tables 4.3 4.4)

Table 4.3: Model Summary

\begin{tabular}{|l|l|l|l|l|}
\hline Model & R & R Square & $\begin{array}{l}\text { Adjusted R } \\
\text { Square }\end{array}$ & $\begin{array}{l}\text { Std. Error of } \\
\text { the Estimate }\end{array}$ \\
\hline 1 & $.940^{\text {a }}$ & .884 & .866 & .931 \\
\hline
\end{tabular}

Table 4.4: ANOVA

\begin{tabular}{|c|c|c|c|c|c|c|}
\hline \multicolumn{2}{|c|}{ Model } & \multirow{2}{*}{\begin{tabular}{|l|}
$\begin{array}{l}\text { Sum } \\
\text { Squares }\end{array}$ \\
251.479
\end{tabular}} & \multirow{2}{*}{$\begin{array}{l}\text { Df } \\
6\end{array}$} & \multirow{2}{*}{\begin{tabular}{|l} 
Mean Square \\
41.913 \\
\end{tabular}} & \multirow{2}{*}{$\begin{array}{l}F \\
48.315\end{array}$} & \multirow{2}{*}{\begin{tabular}{|l} 
Sig. \\
$.000^{\mathrm{b}}$
\end{tabular}} \\
\hline \multirow{3}{*}{1} & Regression & & & & & \\
\hline & Residual & 32.965 & 38 & .868 & & \\
\hline & Total & 284.444 & 44 & & & \\
\hline \multicolumn{7}{|c|}{ a. Dependent Variable: IFR } \\
\hline \multicolumn{7}{|c|}{ b. Predictors: (Constant), LOSS, BO, GOV, ID, LOG(SIZE), MO } \\
\hline
\end{tabular}

Table 4.3 shows the results of regression obtained after performing strong diagnostics. The table shows that the value of $\mathrm{R}$ square for the model with dependent variable IFR is 0.884 . This shows that $88.4 \%$ of variations in the dependent variable IFR are explained *due to the independent variables of the model. The remaining set of $11.4 \%$ of variations remained unexplained by the set of independent and control variables (governance, managerial ownership, percentage of block holders, percentage of independent directors, log of size and loss made in the operating years). The $11.4 \%$ of unexplained variations in the model account for the error term in the model. It is generally assumed that value of R square closer to 1 shows that the model is best fit. As the value of $\mathrm{R}$ square is 0.884 which is near to 1 , so model is best fit and estimates obtained for the variables are reliable. In addition to this, the findings of ANOVA presented in table 4.4 show that the value of F-Statistics is 48.315 . This value is significant at $1 \%$ level of significance. This significance of F-Statistics further confirms that the model with IFR as dependent variable is reliable and stable.

\section{Coefficients statistics}

The value of estimates obtained for the variables from the regression analysis are presented below in coefficient table 4.5 .

Table 4.5: Coefficients

\begin{tabular}{|c|c|c|c|c|c|c|}
\hline \multicolumn{2}{|c|}{ Model } & \multicolumn{2}{|c|}{ Unstandardized Coefficients } & $\begin{array}{l}\text { Standardized } \\
\text { Coefficients } \\
\text { Beta } \\
\end{array}$ & $\mathrm{T}$ & Sig. \\
\hline \multirow{7}{*}{1} & (Constant) & -4.683 & 1.180 & & -3.969 & .000 \\
\hline & GOV & 5.056 & .542 & .632 & 9.327 & .000 \\
\hline & MO & -4.300 & .321 & -1.094 & -13.388 & .000 \\
\hline & $\mathrm{BO}$ & -.027 & .008 & -.274 & -3.445 & .001 \\
\hline & ID & .090 & .015 & .378 & 6.037 & .000 \\
\hline & LOG(SIZE) & 1.585 & .149 & .808 & 10.664 & .000 \\
\hline & LOSS & .209 & .550 & .024 & .380 & .706 \\
\hline
\end{tabular}


Table 4.5 shows that the value of governance coefficient is 5.056 . This coefficient is found to be significant at $1 \%$ level of significance. This positive and significant value of coefficient for governance show that shareholders voting rights in the bank of Nigeria has positive impact on the IFR disclosures made by them. A unit increase in shareholders voting rights will bring 5.056 units increase in the level of IFR of Nigerian banks. The findings of the study are consistent with the findings of Kelton and Yang (2008) which gives more credence to my research. These findings leads to the rejection of hypothesis $\mathrm{H} 1$ proposed for the study which asserts that the internet based disclosure of a Bank's level is linked negatively with the rights of shareholders. The findings suggest that the banks with strong shareholders right have high level of corporate governance and they provide more financial disclosures on their official websites.

The regression analysis shows that the value of coefficient for percentage of managerial ownership is -4.3 . This value is significant at $1 \%$ level of significance. This significant value of managerial ownership coefficient shows that an increase in level of managerial ownership in Nigerian banks will lead towards a decrease in their disclosures made on internet sources. The results supports the findings of Eng and Mak (2003) who has also found a negative relationship of managerial ownership with IFR of firms operating in Singapore. The estimates of regression for managerial ownership leads towards the acceptance of hypothesis $\mathrm{H} 2$ proposed for the study that the internet based disclosure of a Bank's level is linked negatively with its managerial ownership.

The estimations done for examining the impact of block holder's ownership on IFR of banks in Nigeria also reveal a significant but negative relationship between the two. The value of correlation coefficient for these two is -0.027 and is significant at $1 \%$ level of significance. The results show that an increase in block holders ownership will also lead towards a decrease in internet financial reporting of Nigerian banks. The results of the current study are in accordance with the studies of Mitchell et al., (1995) and Schadewitzand Blevins (1998) that also observed a negative association of block holder's ownership with the level of IFR hence gives relevance to the research. These findings support the acceptance of hypothesis $\mathrm{H} 3$ which states that the internet based disclosure of a Bank's level is linked negatively with its Block ownership.

The regression result for the fourth independent variable that is independent director's show that there exists a positive and significant of independent directors on the IFR of banks in Nigeria. Here the value of estimated coefficient is 0.090 which is found to be significant at $1 \%$ level of significance. It can be inferred from the findings of regression estimate that an increase in level of independent directors in board will enhance the transparency of banks and lead towards an increase in financial disclosures on official websites. The results for independent director and IFR further strengthen the findings of Beasley (1996), Chen and Jaggi (2000) and Xiao et al., (2004). These results leads towards the rejection of hypothesis $\mathrm{H} 4$ proposed for the study. The hypothesis $\mathrm{H} 4$ is rejected because it asserts that there is no linkage between internet based disclosure of a Bank's level and its independent director's proportion on the board. Whereas, the estimates of regression show that presence of independent directors in the board has a positive and significant impact on internet financial reporting of banks.

The results for the control variables show that the size of banks measured in terms of shareholders equity has a significant and positive impact on the IFR. The findings show that a unit increase in size of Nigerian banks will lead towards an increase in bank internet disclosures by 1.585 units as value of coefficient is 1.585 which is significant at $1 \%$ level of 
significance. These findings for the relationship between firm size and internet financial reporting in Nigeria is in accordance with literature as the prior studies conducted by Chow and Wong-Boren (1987) and Lang and Lundholm, (1993) has also observed the same association between these two.

The estimates of regression analysis for loss made by firms in operating year and IFR also indicate the presence of positive impact of loss on IFR. However, this relationship is not found to have significant impact on IFR of banks in Nigeria.

\section{DISCUSSION AND FINDINGS}

To empirically examine the impact of corporate governance on IFR of banks in Nigeria, the top ten listed banks in Nigeria were selected. The data on the banks were collected through the secondary sources that were official websites and bank annual reports from year 2010 to 2015. The variables selected for analyzing the impact of corporate governance on IFR include IFR made up of 10 Format and content items and four variables as a measure of corporate governance. The variables that were used as measure of corporate governance include governance (proxy for shareholders voting rights), percentage of managerial ownership, percentage of block holder's ownership and percentage of independent directors on board. For empirically testing the impact of corporate governance on IFR of Nigerian banks, the descriptive analysis, correlation analysis and regression analysis was performed.

The findings obtained through descriptive analysis show that the mean level of IFR of banks in Nigeria on the ten item scale is 6.89 which indicates that the banks in Nigeria are required to have focus on enhancing the level of transparency through internet based disclosures as the attention is paid high on content items than the format items. The banks have given the voting rights to their shareholders as mean value for it is 0.80 . The mean value of managerial ownership in Nigerian banks is $0.8530 \%$ whereas the value is $29.10 \%$ for level of block holder's ownership in banks. The boards of banks in Nigeria have an average percentage of $33.33 \%$ of independent directors in their board. The descriptive also show that Nigerian banks have mean level of equity 61643195.10 NGN and all the banks have employed BIG4 audit firms for audit. The correlation analysis shows that IFR holds negative and significant relationship with managerial ownership. However the relationship is positive but insignificant relationship with shareholder voting rights, block holders ownership in Nigerian banks. The findings of correlation analysis also show that IFR holds insignificant relationship with the size of banks and loss made by them in the year of operations.

The regression model was also run for estimating the impact of corporate governance measures on IFR of Nigerian Banks. The R square with value 0.884 and significant F-Statistics show that model selected for analyzing the impact of corporate governance on IFR is best fit and estimates obtained from model are reliable. The findings of regression show that banks in Nigeria have offered more disclosures for showing the investors that they have good governance. The results support the signaling theory argument in Nigeria (Kelton and Yang, 2008). The banks in Nigeria are suggested to give more voting rights to the shareholders and are required to disclose more financial information on internet to signal investors that their level of transparency is enhanced and their governance is good as there is low information asymmetry and agency cost between the managers and shareholders. The hypothesis $\mathrm{H} 1$ is rejected on the basis of findings of regression analysis. On the basis of regression analysis findings, it can be predicted that increase in level of managerial ownership will leads to decrease in need for IFR in Nigeria. The regression estimates leads towards the acceptance of hypothesis $\mathrm{H} 2$ proposed for study that the internet based disclosure of a Bank's level is linked negatively with its managerial ownership. The findings support the Jensen and Meckling 
(1976) view that an increase in managerial ownership will reduce the level of agency cost by reconciling the interests of shareholders and managers. Hence the agency problems are resolved and the value of firm is enhanced due to increase in interest of managers on productivity and innovation in business. This in turn generates low demand for IFR as low level of monitoring efforts is required on the part of shareholders.

The research findings also show that block holder's ownership has significant impact on IFR of banks in Nigeria. It is inferred from the regression results that an increase in block holders ownership will also lead towards a decrease in IFR of Nigerian banks. The results of the current study are in accordance with the studies of Mitchell et al., (1995) and Schadewitz and Blevins (1998) and support the acceptance of hypothesis $\mathrm{H} 3$ which states that the internet based disclosure of a Bank's level is linked negatively with its Block ownership. The findings suggest the banks in Nigeria with an increase in percentage of block holders with equity more than $5 \%$ lowers the level of need of banks for disclosure made through internet as less monitoring is required. In addition to this, the rejection of hypothesis $\mathrm{H} 4$ that there is no linkage between internets based disclosure of a Bank's level and its independent director's proportion on the board assert that independent directors have a positive and significant impact on the IFR of banks in Nigeria. The findings contradict the findings of Eng and Mak (2003) who found a negative influence of board independence on IFR in their study in Singapore. The regression estimate proves that an increase in level of independent directors in board will enhance the transparency of banks and lead towards an increase in financial disclosures on official websites. This is because of the reason that presence of independent directors in high percentage on board enhances the reliability of corporate financials and ensures that banks have efficient monitoring of earnings. The level of internet financial reporting in banks with independent directors is enhanced due to decision of independent directors for making voluntary disclosures.

On the basis of the findings, it is obvious that measures of corporate governance have significant influence on the level of IFR of banks in Nigeria. The banks in Nigeria are suggested to have high percentage of managerial ownership and block holders' ownership if they want to have low level of internet financial reporting. In contrast to this, the banks that want to disclose more frequently on their official websites are suggested to have an increase in representation of independent directors on their board or are advised to give more voting rights to shareholders as in such scenarios more information is required to the shareholders for monitoring the activities of management and to reduce agency cost. Furthermore, the banks are also advised to have more frequent disclosures on their websites if they have high level of shareholders equity as a source of fund in capital structures.

\section{CONCLUSION AND RECOMMENDATIONS}

The main objective of the study was to examine the impact of corporate governance on IFR among listed banks in Nigeria. For that purpose a review of existing literature was carried out. On the basis of literature review, it is concluded that internet financial reporting is one of the most efficient means of communicating investors (Ashbaugh et al., 1999). The reporting of financial information through the internet is a flexible way of communication as businesses can disclose information in different formats which in turn enhances the level of transparency of firms. The literature shows that the corporate governance practices in a firm also influence its level of disclosures made through internet. (Chen and Jaggi 2000; Eng and Mak 2003; Gul and Leung, 2004 and Kelton and Yang 2008). 
Empirically examining the impact of corporate governance practices on IFR in the growing economy of Nigeria, quantitative research was carried out where the relationship between corporate governance variable and IFR was empirically examined. The data on the top ten listed banks in Nigeria was collected from the secondary sources for year 2010 to 2015. The study conducted was deductive in nature. The data was empirically analyzed by employing the following statistical tools; descriptive analysis, correlation analysis and regression analysis.

The findings of empirical investigation suggest that the measures of corporate governance have significant influence on the level of IFR of banks in Nigeria. The findings show that shareholder' voting rights, percentage of independent directors and bank size have significant positive impact on the IFR of banks. The banks in Nigeria make more disclosures on internet when their shareholders have strong voting rights, have high percentage of independent directors on board and greater firm size. However, low level of financial disclosures through internet is evident in case where the banks have high percentage of managerial ownership and high percentage of block holders with more than 5\% equity. In such cases, banks make less disclosures as less monitoring is required from the shareholders and there is low need for disclosing the information.

The results of the study leads to the acceptance of two hypotheses (H2 and H3) and rejection of two hypotheses (H1 and H4) proposed on the basis of literature.

From the results, it is concluded that measures of corporate governance has significant influence on the level of IFR of banks in Nigeria. Banks in Nigeria with high percentage of managerial ownership and block holders ownership are associated with low level of internet financial reporting. In contrast to this, banks that have a high proportion of representation of independent directors on their board or give more voting rights to shareholders are associated with higher frequency of IFR. Furthermore, the banks are also advised to have more frequent disclosures on their websites if they have high level of shareholders equity as a source of fund in capital structures

On the basis of the findings and empirical estimations, the study recommends Nigerian banks to make frequent disclosures on websites for ascertaining the investors about their virtual presence and to assure investors that they have high level of transparency as they had incorporated the practices of corporate governance of banks. During the research, it was observed that the banks in Nigeria lay more emphasis on the content items while making disclosures on the official websites and the format items are often ignored. Based on this, the banks in Nigeria are also advised to have focus on the format of presentation. They are suggested to present annual reports in multiple formats with established hyperlinks and drop down navigational menus. The focusing on the format of presentation will help in attracting more investors as it will facilitate the potential investors' manipulation of financial data or information and making investment decisions. (Conway, 2012).

\section{FUTURE RESEARCH}

This is an exploratory empirically based research assessing the links between IFR disclosure and corporate governance in Nigerian banks. In the future, the bank communications and the standards will be made solely via the internet. So, it is expected of the banks in Nigeria to be increasingly involved in the disclosure of information on the internet (Kelton and Yang, 2008). This study acts as the IFR benchmark for developing countries in the region and other African countries at large. The collection of data in different countries for more companies especially those with various other regulations for disclosure would improve the results validation in this research and would help in the different identification and similarities in the decisions of 
policy makers. This research explored banks characteristics which were related to the IFR amount and information disclosure sample for banks in Nigeria which had websites. The research in future might also explore how disclosure and IFR impacts the prices of stocks and the share volume trade in Nigeria. It might also test empirically how the banks in Nigeria are impacted by other factors of IFR like dividends, stock prices and to determine how this reporting provides information valuable to the investors. The banks tend to reveal more information in order to limit the asymmetry of the information between investors and themselves. By attracting more bank investors, the capital cost is reduced and is expected for the banks. Therefore, the IFR and corporate governance relationship and cost of capital disclosures could be analyzed in the future.

\section{References}

Abdelsalam, O.H., Bryant, S. M., and Street, D.L. (2007).An examination of comprehensiveness of corporate internet reporting provided by London-listed companies.Journal of International Accounting Research. 6 (2), 1-33.

Ajinkya, B., Bhojraj, S., Sengupta, P. ( 2005). The association between outside directors, institutional investors and the properties of management earnings forecasts. Journal of Accounting Research 43 (3), 343-376

Ashbaugh, J., Johnstone, K.M., Warfield, T.D., (1999). Corporate reporting on the Internet. Accounting Horizons 13 (3), 241-257.

Asogwa, I.E. (2016) Corporate Governance in Nigerian Bnaks: a Theoretical Review, International Journal of Management Science and Business Administration, Vol.2 (7) 7-15

Beasley, M., (1996). An empirical analysis of the relation between the board of director composition and financial statement fraud. The Accounting Review 71 (4), 443-465.

Bhasin, M.L (2012) Voluntary corporate governance disclosure: Evidence from a developing country far East Journal of Psychology and Business Vol. 9 No. 2 PG 10- 31

Bushman, R.M., Piotroski, J.D., Smith, A.J., (2004). What determines corporate transparency? Journal of Accounting Research 42 (2), 207-252.

Chen, C.J.P., Jaggi, B., (2000). Association between independent non-executive directors, family control and financial disclosures in Hong Kong. Journal of Accounting and Public Policy 19, 285-310

Chow, C.W., Wong-Boren, A., (1987). Voluntary financial disclosure by Mexican corporations. The Accounting Review 62 (3), 533-541.

Conway, S.L (2012). Guidelines for Corporate Governance Disclosure - are Australian listed companies conforming? Journal of the Asia-Pacific Centre for Environmental Accountability, 18(1), 5-24.

Damodaran, A.( 2006). Applied Corporate Finance: A Users Manual, 2nd edn, John Wiley and Sons, New York.

Debreceny, R., Gray, G.L., Rahman, A., (2002). The determinants of Internet financial reporting. Journal of Accounting and Public Policy 21, 371-394.

Ejuvbekpokpo, S.A and Esuike, B.U (2013) Corporate governance issues and its implementation:The Nigerian experience. Journal of Research in International Business Management (ISSN: 2251-0028) Vol. 3(2) pp. 53-57

Emmanuel, U. Oki, E.U and Maimako, S. S (2015) Corporate Governance Disclosure Practices and Bank Performance in Nigeria: An Empirical Investigation International Journal of Managerial Studies and Research (IJMSR) Volume 3, Issue 1, January 2015, PP 49-5

Eng, L.L. and Mak, Y.T (2003). “Corporate Governance and Voluntary Disclosure,” Journal of Accounting and Public Policy, 22(4), pp. 325-345

Ettredge, M., Richardson, V.J., Scholz, S., (2002). Dissemination of information for investors at corporate Web sites. Journal of Accounting and Public Policy 21, 357-369

Ezi- Herbert W. and Tsegba I. (2010): Corporate governance and firm performance through ownership structure of Nigerian listed companies. 
Gandia, J. L (2005). Corporate e-governance disclosure in the digital age: an empirical study of Spanish listed companies', Working Paper Series. http://ssrn.com/abstract $=531182$

Gul, F.A., Leung, S., (2004). Board leadership, outside directors' expertise and voluntary corporate disclosure. Journal of Accounting and Public Policy 23, 351-379

Healy, P.M., Palepu, K.G., (2001). Information asymmetry, corporate disclosure, and the capital markets: A review of the empirical disclosure literature. Journal of Accounting and Economics 31, 405-440.

Ho, S.S.M., Wong, K.S., (2001). A study of the relationship between corporate governance structures and the extent of voluntary disclosure. Journal of International Accounting, Auditing and Taxation 10, 139-156

Hodge, F.D., Kennedy, J.J., Maines, L.A.,(2004). Does search facilitating technology improve the transparency of financial reporting? The Accounting Review 79 (3), 687-703

Jensen, M and Meckling, W (1976), 'Theory of the firm: managerial behavior, agency costs, and ownership structure', Journal of Financial Economics, vol. 3, pp. 305-360.

Jiang, Y. and Raghupati, W. (2010).It-Enabled corporate Governance: the characteristics and determinants of Webbased corporate Governance disclosures, Information Resources Management Journal, 23(4), 1-20

Kelton, A.S and Yang, Y (2008).The impact of corporate governance on internet financial reporting. Journal of Accounting and Public Policy, 27: 62-87

Klein, A., (2002). Audit committee, board of director characteristics, and earnings management. Journal of Accounting and Economics 33 (3), 375-400

Kurawa, J.M and Kabara, A.S (2014) Impact of Corporate Governance on Voluntary Disclosure by Firms in the Downstream Sector of the Nigerian Petroleum Industry. Proceedings of World Business Research Conference 21 23 April 2014, Novotel World Trade Centre, Dubai, UAE

Lang, M., Lundholm, R., (1993). Cross-sectional determinants of analyst ratings of corporate disclosures. Journal of Accounting Research 31 (2), 246-271.

Mitchell, J.D., Chia, C.W.L., Loh, A.S., (1995). Voluntary disclosure of segment information: Further Australian evidence. Accounting and Finance 35 (2), 1-16.

Ogbechie,C (2006): Corporate Governance A Challenge For Nigerian Banks. Cited From www.Businessdayonline.com .

Outa E, R., (2014) The new international financial architecture: Lessons and experiences from Africa

Oyelere, P., Laswad, F., Fisher, R., (2003). Determinants of Internet financial reporting by New Zealand companies. Journal of International Financial Management and Accounting 14 (1), 26-63

Pereiro, L. (2002), Valuation of Companies in Emerging Markets: A Practical Approach,John Wiley and Sons, New York.

Pratt, J.W., Zeckhauser, R.J., (1985). Principals and Agents: The Structure of Business. Harvard Business School Press, Boston

Ranti, U.O., (2011) Corporate Governance and Financial Performance of Banks: A study of listed banks in Nigeria. $\mathrm{Ph} \mathrm{D}$ thesis Covenant University, Ota, Ogun State

Robinson, T. \& Munter, P. (2004). Financial Reporting Quality: Red Flags and Accounting Warning Signs.

Commercial Lending Review. , 1-15Retrieved from: http:// www.tsi-

thailand.org/images/stories/TSI2012 Professional/Download/CISA2 FinancialReportingQuality.pdf (accessed on 27th Dec, 2016)

Roger, D., Glen, L.G. and Asheq R. (2002). The determinants of Internet financial reporting.Journal of Accounting and Public Policy 21(4-5), 371-394.

Sanusi, L. S. (2010). The Nigerian Banking Industry: what went wrong and the way forward. Delivered at Annual Convocation Ceremony of Bayero University, Kano held on, 3(1), 2010.

Sayogo, D.S (2006). The determinants of corporate governance disclosure through internet for companies listing in Jakarta stock exchange. Simposium Nasional Akuntansi 9 Padang 
Ikenna, E. A. (2017). Impact Of Corporate Governance On Internet Financial Reporting In A Growing Economy: The Case Of Nigeria. Archives of Business Research, 5(2), 180-202

Schadewitz, H.J., Blevins, D.R., (1998). Major determinants of interim disclosures in an emerging market. American Business Review 16 (1), 41-55.

Sengupta, P.,( 2004). Disclosure timing: Determinants of quarterly earnings release dates. Journal of Accounting and Public Policy 23, 457-482.

Soludo, C. C. (2004): Consolidating the Nigerian Banking Industry to Meet the Development Challenges of the 21st Century. Being an Address to the special Meeting of Bankers Committee, Held on July 6

Tomasic, R and Bottomley, S (1993), Directing the Top 500: Corporate Governance and Accountability in Australian Companies, Allen and Unwin, Sydney

Umoren, A. 0 and Asogwa, I.E. (2011): corporate factors influencing mandatory disclosures. A study of Nigerian listed companies. The Nigerian accounting Horizon vol.4 No. 1

Xiao, J. Z and Jones M. J (2005), A conceptual framework for investigating the impact of the internet on corporate financial reporting, The International Journal of Digital Accounting Research, 5(10), 131-169

Xiao, J.Z., Yang, H., Chow, C.W., (2004). The determinants and characteristics of voluntary Internet-based disclosures by listed Chinese companies. Journal of Accounting and Public Policy 23, 191-225.

\section{Appendix}

Table 4.1: Descriptive Statistics

\begin{tabular}{|l|l|l|l|l|l|}
\hline & $\mathrm{N}$ & Minimum & Maximum & Mean & Std. Deviation \\
\hline IFR & 50 & 3 & 10 & 6.89 & 2.543 \\
\hline GOV & 50 & 0 & 1 & .80 & .404 \\
\hline MO(\%) & 50 & .0160 & 1.9 & .853040 & .6220372 \\
\hline BO(\%) & 50 & .0000 & 85.0000 & 29.107800 & 25.0553974 \\
\hline ID(\%) & 50 & .0000 & 33.3333 & 15.730660 & 10.1581153 \\
\hline SIZE(NGN, 000) & 50 & 13589 & 277410727 & 61643195.10 & 83349048.722 \\
\hline LOSS & 50 & 0 & 1 & .10 & .303 \\
\hline BIG4 & 50 & 1 & 1 & 1.00 & .000 \\
\hline Valid N (listwise) & 50 & & & & \\
\hline
\end{tabular}


Table 4.2: Correlation Analysis

\begin{tabular}{|c|c|c|c|c|c|c|c|c|c|}
\hline & & IFR & GOV & MO & $\mathrm{BO}$ & ID & LOG(SIZE) & LOSS & BIG4 \\
\hline \multirow{3}{*}{ IFR } & \begin{tabular}{|l} 
Pearson \\
Correlation
\end{tabular} & 1 & .125 & $-.565^{* *}$ & .282 & .288 & .194 & -.048 & $\mathrm{~b}$ \\
\hline & Sig. (2-tailed) & & .413 & .000 & .061 & .055 & .202 & .753 & . \\
\hline & $\mathrm{N}$ & 45 & 45 & 45 & 45 & 45 & 45 & 45 & 45 \\
\hline \multirow{3}{*}{ GOV } & \begin{tabular}{|l|} 
Pearson \\
Correlation
\end{tabular} & .125 & 1 & .254 & -.275 & .069 & $-.458^{* *}$ & -.167 &.$b$ \\
\hline & Sig. (2-tailed) & .413 & & .075 & .053 & .632 & .002 & .247 & . \\
\hline & $\mathrm{N}$ & 45 & 50 & 50 & 50 & 50 & 45 & 50 & 50 \\
\hline \multirow{3}{*}{ MO } & \begin{tabular}{|l} 
Pearson \\
Correlation
\end{tabular} & $\begin{array}{l}. \\
.565^{* *}\end{array}$ & .254 & 1 & $\begin{array}{l}- \\
.573^{* *}\end{array}$ & .185 & .237 & -.229 &. $\mathrm{~b}$ \\
\hline & Sig. (2-tailed) & .000 & .075 & & .000 & .197 & .117 & .109 & . \\
\hline & $\mathrm{N}$ & 45 & 50 & 50 & 50 & 50 & 45 & 50 & 50 \\
\hline \multirow{3}{*}{ BO } & $\begin{array}{l}\text { Pearson } \\
\text { Correlation }\end{array}$ & .282 & -.275 & $-.573^{* *}$ & 1 & $\begin{array}{l}- \\
.303^{*} \\
\end{array}$ & .231 & .052 &. $\mathrm{~b}$ \\
\hline & Sig. (2-tailed) & .061 & .053 & .000 & & .032 & .126 & .718 & . \\
\hline & $\mathrm{N}$ & 45 & 50 & 50 & 50 & 50 & 45 & 50 & 50 \\
\hline \multirow{3}{*}{ ID } & \begin{tabular}{|l|} 
Pearson \\
Correlation \\
\end{tabular} & .288 & .069 & .185 & $-.303^{*}$ & 1 & .001 & $.329^{*}$ &. $\mathrm{~b}$ \\
\hline & Sig. (2-tailed) & .055 & .632 & .197 & .032 & & .996 & .020 & . \\
\hline & $\mathrm{N}$ & 45 & 50 & 50 & 50 & 50 & 45 & 50 & 50 \\
\hline \multirow{3}{*}{ LOG(SIZE) } & \begin{tabular}{|l|} 
Pearson \\
Correlation
\end{tabular} & .194 & $.458^{* *}$ & .237 & .231 & .001 & 1 & -.116 &. $\mathrm{~b}$ \\
\hline & Sig. (2-tailed) & .202 & .002 & .117 & .126 & .996 & & .448 & . \\
\hline & $\mathrm{N}$ & 45 & 45 & 45 & 45 & 45 & 45 & 45 & 45 \\
\hline \multirow{3}{*}{ LOSS } & \begin{tabular}{|l|} 
Pearson \\
Correlation
\end{tabular} & -.048 & -.167 & -.229 & .052 & $-329^{*}$ & -.116 & 1 &. $\mathrm{~b}$ \\
\hline & Sig. (2-tailed) & .753 & .247 & .109 & .718 & .020 & .448 & & . \\
\hline & $\mathrm{N}$ & 45 & 50 & 50 & 50 & 50 & 45 & 50 & 50 \\
\hline \multirow{3}{*}{ BIG4 } & \begin{tabular}{|l|} 
Pearson \\
Correlation
\end{tabular} & $\mathrm{b}$ &. $\mathrm{b}$ &.$b$ & $\mathrm{~b}$ &. $\mathrm{~b}$ & b & b & $\mathrm{b}$ \\
\hline & Sig. (2-tailed) &. & . & . & . & $\cdot$ & $\cdot$ & 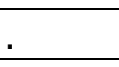 & \\
\hline & $\mathrm{N}$ & 45 & 50 & 50 & 50 & 50 & 45 & 50 & 50 \\
\hline
\end{tabular}

Table 4.3: Model Summary

\begin{tabular}{|l|l|l|l|l|}
\hline Model & $\mathrm{R}$ & R Square & $\begin{array}{l}\text { Adjusted R } \\
\text { Square }\end{array}$ & $\begin{array}{l}\text { Std. Error of } \\
\text { the Estimate }\end{array}$ \\
\hline 1 & $.940^{\mathrm{a}}$ & .884 & .866 & .931 \\
\hline
\end{tabular} $\begin{aligned} & \text { a. Predictors: (Constant), LOSS, BO, GOV, ID, LOG(SIZE), } \\
& \text { MO }\end{aligned}$


Ikenna, E. A. (2017). Impact Of Corporate Governance On Internet Financial Reporting In A Growing Economy: The Case Of Nigeria. Archives of

Table 4.4: ANOVA

\begin{tabular}{|l|l|l|l|l|l|l|}
\hline \multicolumn{2}{|l|}{ Model } & $\begin{array}{l}\text { Sum } \\
\text { Squares }\end{array}$ & of Df & Mean Square & F & Sig. \\
\hline \multirow{3}{*}{1} & Regression & 251.479 & 6 & 41.913 & 48.315 & $.000^{\mathrm{b}}$ \\
\cline { 2 - 7 } & Residual & 32.965 & 38 & .868 & & \\
\cline { 2 - 7 } & Total & 284.444 & 44 & & & \\
\hline \multicolumn{2}{|l|}{ a. Dependent Variable: IFR } \\
\multicolumn{2}{|l|}{ b. Predictors: (Constant), LOSS, BO, GOV, ID, LOG(SIZE), MO } \\
\hline
\end{tabular}

Table 4.5: Coefficients

\begin{tabular}{|c|c|c|c|c|c|c|}
\hline \multirow{2}{*}{\multicolumn{2}{|c|}{ Model }} & \multicolumn{2}{|c|}{$\begin{array}{l}\text { Unstandardized } \\
\text { Coefficients }\end{array}$} & \multirow{2}{*}{$\begin{array}{l}\text { Standardized } \\
\text { Coefficients } \\
\text { Beta }\end{array}$} & \multirow[t]{2}{*}{$\mathrm{T}$} & \multirow[t]{2}{*}{ Sig. } \\
\hline & & B & Std. Error & & & \\
\hline \multirow{7}{*}{1} & (Constant) & -4.683 & 1.180 & & -3.969 & .000 \\
\hline & GOV & 5.056 & .542 & .632 & 9.327 & .000 \\
\hline & \begin{tabular}{|l|} 
MO \\
\end{tabular} & -4.300 & .321 & -1.094 & -13.388 & .000 \\
\hline & BO & -.027 & .008 & -.274 & -3.445 & .001 \\
\hline & \begin{tabular}{|l|} 
ID \\
\end{tabular} & .090 & .015 & .378 & 6.037 & .000 \\
\hline & LOG(SIZE) & 1.585 & .149 & .808 & 10.664 & .000 \\
\hline & LOSS & .209 & .550 & .024 & .380 & .706 \\
\hline
\end{tabular}

